\title{
COMMENTS
}

\section{SECULAR IDOLATRY AND SACRED TRADITIONS: A GRITIQUE OF THE SUPREME COURT'S SECULARIZATION ANALYSIS}

\author{
ALEXANDRA D. FURTH ${ }^{\dagger}$
}

\section{INTRODUCTION}

The Supreme Court's Establishment Clause jurisprudence has generated great controversy and received virulent criticism from people on both sides of the constitutional debate. The Court's analysis attempts to delineate the boundaries between religion and secular society, raising fundamental questions about the role of religion in the lives of individuals and in the public sphere. Such constitutional determinations strike at the very core of the American identity, potentially jeopardizing long-held traditions. Furthermore, these issues beg metaphysical questions about the definition of "religion" and the role of both religion and history in the evaluation of potentially unconstitutional practices. As part of this legal challenge, the Supreme Court has engaged in the controversial task of ascertaining whether seemingly religious practices and symbols are in fact religious, or whether history and collective experience have purged them of their religious significance.

By distinguishing practices that are religious from those that "have lost any true religious significance,"1 the Court has engaged in a "secularization" of religious practices and symbols. Examples include

† B.A. 1993, Williams College; J.D. Candidate 1998, University of Pennsylvania. I would like to thank Professor Pamela Harris for helping me develop this Comment and for generously reviewing multiple drafts, and the members of the University of Pennsylvania Law Review for their time and effort in editing. I would also like to thank my parents, Richard and Eileen Furth, and my friends for their unwavering support. I would like to thank my sister, Leslie Furth, for her editorial help and, more generally, for her wisdom and patience.

${ }^{1}$ Marsh v. Chambers, 463 U.S. 783, 818 (1983) (Brennan, J., dissenting). 
state-sponsored religious displays ${ }^{2}$ and invocations of God in the Pledge of Allegiance and other national mottoes. ${ }^{3}$ Although secularizing religious practices conveniently preserves the inclusion of symbols and practices that many Americans understand as fundamental to American identity, it also threatens the purity and integrity of both government and religion. In addition, such strained legal justification jeopardizes the historically neutral relationship between religion and the state.

The Court's adoption of this type of fact-specific inquiry also presents a larger and more daunting question: What is at stake in defining a given practice as either truly religious or secularized by time and tradition? This Comment explores the motivations behind the secularizing of religious symbols and practices, as well as the implications of sanctioning those symbols and practices with legal authority, and argues for an alternative analysis.

Part I of this Comment provides a background of traditional Supreme Court Establishment Clause analysis. Part II describes recent changes in Establishment Clause analysis, particularly the secularization of religious practices. It discusses the foundations of this trend and analyzes several examples, including the secularization of religious practices and symbols in two contexts: public displays and national invocations of religion. In addition, Part II critiques the logic of the Court's secularization analysis, arguing that the Court's rationalization is both inadequate and spurious. Part III examines the academic notion of "civil religion," a concept that has been embraced by the Supreme Court in its efforts to justify secularization of religion. Part IV discusses the detrimental effects of the Court's secularization of religious practices and symbols, and considers the ways in which secularization injures religion, society, and the individual. Part V suggests a theory for why the Court continues to embark on its mission-in spite of the conspicuous perils that accompany seculariza-

${ }^{2}$ See County of Allegheny v. ACLU, 492 U.S. 573, 621 (1989) (upholding display of Chanukah menorah on municipal property); Lynch v. Donnelly, 465 U.S. 668, 687 (1984) (upholding display of a municipally sponsored crèche).

${ }^{3}$ See Allegheny, 492 U.S. at $602-03$ (assuming that while a crèche might be unconstitutional, the Pledge of Allegiance is obviously distinguishable); Lynch, 465 U.S. at 676 (citing the Pledge and "In God We Trust" as examples of constitutionally permissible references to our national heritage); see also School Dist. of Abington Township v. Schempp, 374 U.S. 203, 304 (1963) (Brennan, J., concurring) (speculating that "under God" in the Pledge is merely an allusion to a "historical fact"); Sherman v. Community Consol. Sch. Dist. 21, 980 F.2d 437, 439 (7th Cir. 1992) (rejecting challenge to the constitutionality of "under God" in the Pledge of Allegiance). 
tion-and how the damage can be minimized. In particular, this Part argues that the persistent compulsion to retain religious practices and symbols in public life is due, in part, to a collective crisis of American identity and attendant fears of an evolving identity that excludes religion. Finally, this Comment argues for a repudiation of the Supreme Court's secularization analysis and a return to a faithful Establishment Clause jurisprudence.

\section{TRADITIONAL ESTABLISHMENT CLAUSE ANALYSIS}

The Supreme Court's Establishment Clause ${ }^{4}$ analysis has been attacked by commentators from all sides of the constitutional and religious debate since the Supreme Court embarked on its first attempts to articulate a coherent doctrine. ${ }^{5}$ Criticism of the Court's analysis has focused on recent decisions that specifically delineate which practices are truly religious and therefore violate the Constitution. ${ }^{6}$ However, the Court's ambivalence about the appropriate role of religion in public life, as well as the proper means for analyzing such issues, has been apparent since its earliest decisions.

In its original incarnation, the Supreme Court's church and state doctrine appeared to be certain and resolute. In Everson $v$. Board of Education, the Court upheld a New Jersey statute that provided for reimbursement to parents for costs of transporting children to public or parochial schools. ${ }^{7}$ The Court reasoned that, although parents of

1 The Establishment Clause provides that "Congress shall make no law respecting an establishment of religion." U.S. CONST. amend. I.

${ }^{5}$ See Stephen L. CARTER, THE CULTURE OF Disbelief 109 (1993) ("The embarrassing truth is that the Establishment Clause has no theory."); LEONARD W. LEVY, THE ESTABLISHMENT CLAUSE 220 (2d rev. ed. 1994) ("The Supreme Court has been inexcusably inconsistent in its interpretation of the establishment clause."); William P. Marshall, "We Know It When We See It": The Supreme Court and Establishment, 59 S. CAL. L. REV. 495, 495 (1986) ("From the outset it has been painfully clear that logical consistency and establishment clause jurisprudence were to have little in common.").

6 See, e.g., Leo PfeFFer, RELIGION, STATE, AND THE BuRger COURT 124 (1984) (arguing that the Court's treatment of religious minorities in Lynch is similar to its treatment of racial minorities in the Dred Scott decision); Laurence H. Tribe, Constitutional Calculus: Equal Justice or Economic Efficiency?, 98 HARV. L. REV. 592, 610-11 (1985) (noting that the Court's finding in Lynch, that any endorsement of religion was merely "incidental" and could not outweigh the "secular" function of celebrating the holiday season, was similar to the finding that there was "nothing invidious" in Jim Crow laws); Irving R. Kaufman, Where Christmas Belongs, WALL ST. J., Dec. 19, 1991, at A15 (noting the dangers associated with allowing the Court to determine the religiousness of practices and speculating on the dire consequences of "this misguided substitution of assigned roles-jurist as spiritual mentor, legislator as itinerant preacher").

730 U.S. 1,17 (1947). 
students attending parochial school were eligible for assistance, the program did not aid religion. ${ }^{8}$ In spite of the specific holding, the Court stated a firm and unambiguous prohibition of church and state integration:

The "establishment of religion" clause of the First Amendment means at least this: Neither a state nor the Federal Government can set up a church. Neither can pass laws which aid one religion, aid all religions, or prefer one religion over another. Neither can force nor influence a person to go to or to remain away from church against his will or force him to profess a belief or disbelief in any religion. No person can be punished for entertaining or professing religious beliefs or disbeliefs, for church attendance or non-attendance. No tax in any amount... can be levied to support any religious activities or institutions, whatever they may be called, or whatever form they may adopt to teach or practice religion. Neither a state nor the Federal Government can, openly or secretly, participate in the affairs of any religious organizations or groups and vice versa.

In addition to articulating an emphatically separationist policy, the Court specifically stated that the First Amendment (and therefore the Establishment Clause) applied to both the federal government and the states. ${ }^{10}$ Invoking Thomas Jefferson's concept of a "wall of separation between church and state," the Court maintained that the "wall must be kept high and impregnable,"12 apparently leaving little room for future debate.

In spite of its auspicious beginning, the Supreme Court's church and state doctrine later became equivocal, uncertain, and fiercely contested. Although the principle of neutrality developed in Everson prevailed in the decades following the decision, the concept was constantly reinterpreted and manipulated. ${ }^{13}$ Over time, the Court's opinions adopted various analyses yielding unpredictable results, ${ }^{14}$ and its

${ }^{8}$ The Court determined that the program "does no more than provide a general program to help parents get their children, regardless of their religion, safely and expeditiously to and from accredited schools." Id. at 18.

${ }^{9} I d$. at $15-16$.

${ }^{10}$ See id. at 15.

${ }^{11} I d$. at 16 (quoting Reynolds v. United States, 98 U.S. 145, 164 (1878) (quoting Jefferson)).

${ }^{12} I d$. at 18.

${ }^{13}$ See Timothy L. Hall, Sacred Solemnity: Civic Prayer, Civil Communion, and the Establishment Clause, 79 IOWA L. REv. 35, 37 (1993) ("[T]he concept of neutrality dwells at an elevated level of abstraction and is susceptible to manipulation from a wide spectrum of perspectives.").

${ }^{14}$ See, e.g., Lemon v. Kurtzman, 403 U.S. 602, 612-13 (1971) (subjecting a challenged law or practice to a three-part test); Lynch v. Donnelly, 465 U.S. 668, 690 
consensus on mandatory and absolute separation of church and state as expressed in Everson dissolved. ${ }^{15}$ Until 1971, when the Supreme Court decided Lemon v. Kurtzman and announced a formal test for practices and laws challenged under the Establishment Clause, ${ }^{16}$ the Court's decisions relied on a somewhat ad hoc methodology.

According to the Lemon test, a practice or law does not violate the Establishment Clause if it has a valid secular purpose, does not have a primary effect that either advances or inhibits religion, and does not create excessive entanglement of government and religion. ${ }^{17} \mathrm{Al}-$ though the Lemon test seems to provide sufficient guidance, it has failed in two important respects. First, the rule has not garnered the necessary support from the Court. ${ }^{18}$ Second, it provides no guidance for determining when a challenged practice or symbol is sufficiently "religious" to trigger rigorous Establishment Clause analysis. Although the formal rule articulated in Lemon has survived, the rule is of limited value, as it does not provide a vehicle for assessing religiousness and is not uniformly applied. ${ }^{19}$ Thus, the determination of how and when practices violate the Constitution has evolved as a nebulous and highly subjective process.

\section{The SEcularization OF RELIGION}

In the absence of a systematic means for ascertaining when a challenged practice is sufficiently nonreligious to survive Establishment Clause analysis, the Supreme Court has determined religiousness on a

(1984) (O'Connor, J., concurring) (arguing that the appropriate inquiry was whether a challenged practice or statute endorsed religion); Lee v. Weisman, 505 U.S. 577, 592 (1992) (stating that the relevant question was whether the challenged practice was coercive).

${ }^{15}$ Compare Lee, 505 U.S. at 599 (striking down a school graduation prayer), with id. at 642-44 (Scalia, J., joined by Rehnquist, C.J., and White \& Thomas, JJ., dissenting) (arguing that school-sponsored graduation prayer did not violate the Establishment Clause).

t6 403 U.S. at 612.

17 See id. at 612-13.

${ }^{18}$ See, e.g., Lee, 505 U.S. at 644 (Scalia, J., joined by Rehnquist, C.J., and White \& Thomas, IJ., dissenting) (arguing that the Lemon test is irrelevant and suggesting that the majority opinion had properly ignored the test); Edwards v. Aguillard, 482 U.S. $578,636-40$ (1987) (Scalia, J., dissenting) (criticizing the "purpose" prong of the Lemon test); Roemer v. Board of Pub. Works, 426 U.S. 736, 768-69 (1976) (White, J., concurring) (criticizing the "entanglement" prong of the Lemon test).

${ }_{19}$ See, e.g., Marsh v. Chambers, 463 U.S. 783, 792 (1983) (declining to apply the Lemon test to the Nebraska state legislature's practice of opening each session with a prayer). 
case-by-case basis. This Part of the Comment demonstrates how the Court has secularized religious practices by discussing several examples. In addition, this Part critiques the logic of Supreme Court secularization.

"Secularization," as it is used in this Comment, refers to the Supreme Court's determination that practices and symbols which were once religious have lost their religious significance, through either temporal or contextual erosion. A determination of the true religiousness of contested practices and symbols has not been consistently subjected to Establishment Clause analysis. Rather, the analysis has been selectively employed in an attempt to reconcile religion with tradition. ${ }^{20}$ The standard may be whether a symbol or practice has achieved a threshold level of status in American history and tradition. One commentator speculated that " $[t]$ he comfort of familiarity and the desire for continuity with the past explain continued use of the symbol better than devotion to the content of its meaning." explanation that such practices and invocations are of a national rather than religious significance ${ }^{22}$ reveals a fundamental and deepseeded attachment: To outlaw such practices would be somehow "unAmerican."

${ }^{20}$ Compare Lynch v. Donnelly, 465 U.S. 668, 681 (1984) (holding that a crèche has a secular purpose of depicting history and tradition), and Marsh, 463 U.S. at 795 (upholding daily public prayer by a chaplain employed by the Nebraska state legislature), with School Dist. of Abington Township v. Schempp, 374 U.S. 203, 205 (1963) (striking down a Pennsylvania law that required Bible readings in public school at the opening of each school day). As one critic noted: "The Court has failed to offer a principled justification for holdings that banished civic prayers from public schools ... but permitted civic prayers in state legislative assemblies ...." Hall, supra note 13 , at 41 .

${ }^{21}$ Hall, supra note 13 , at 50 .

${ }^{22}$ See, e.g., Smith v. Denny, 280 F. Supp. 651, 653-54 (E.D. Cal. 1968) (rejecting a challenge to the Pledge of Allegiance, and quoting Sheldon v. Fannin, 221 F. Supp. 766, 774 (D. Ariz. 1963), in which a challenge to mandatory participation in singing the National Anthem was struck down because "[t]he singing of the National Anthem is not a religious but a patriotic ceremony, intended to inspire devotion to and love of country. Any religious references therein are incidental and expressive only of the faith which as a matter of historical fact has inspired the growth of the nation."); $c f$. Schempp, 374 U.S. at 303 (Brennan, J., concurring) ("[W]e have simply interwoven the motto ["In God We Trust"] so deeply into the fabric of our civil polity that its present use may well not present that type of involvement which the First Amendment prohibits."). 


\section{A. Secularization in Practice}

Either by design or as a byproduct of constitutional reasoning, secularization has preserved traditional practices in several different contexts, including public displays and national invocations. ${ }^{23}$ However, even prior to invoking secularization as a justification for preserving religious practices and symbols, the Court expressed its predisposition to sanction some religious practices. These early cases revealed a commitment to historical tradition and a willingness to creatively preserve religious practices in spite of obvious conflicts with the Establishment Clause. In the later cases, the Supreme Court and courts of appeals have carried this inclination a step further by classifying practices and symbols as secular. ${ }^{24}$

\section{A Precursor to Secularization-Deifying History}

In Marsh v. Chambers, the Supreme Court reversed the Eighth Circuit and held that recitation of nondenominational prayers at the opening of the Nebraska state legislature by a Presbyterian minister did not violate the Establishment Clause. ${ }^{25}$ Writing for the majority, Chief Justice Burger emphasized that the Nebraska legislature's practice was not unconstitutional because it was well grounded in United States history: "The opening of sessions of legislative and other deliberative public bodies with prayer is deeply embedded in the history and tradition of this country." ${ }^{26}$ The majority opinion traced the practice back to 1774 when the Continental Congress opened its sessions with a prayer delivered by a paid chaplain. ${ }^{27}$ Although the Bill of Rights had not been drafted at that time, the Marsh opinion noted the 1789 passage of the First Amendment as evidence that the existing practice of employing legislative chaplains was not in conflict with

${ }^{23}$ See, e.g., Lynch, 465 U.S. at 681 (holding that a crèche has the secular purpose of depicting history and tradition); cf. Marsh, 463 U.S. at 792 (upholding legislative prayer as a "part of the fabric of our society").

${ }_{24}$ See, e.g., Sherman v. Community Consol. Sch. Dist. 21, 980 F.2d 437, 445 (7th Cir. 1992) (describing the Pledge of Allegiance as a secular rather than a sectarian vow).

${ }^{25} 463$ U.S. at 795. Although the Court called the prayers "Judeo-Christian," id. at 793, they were often explicitly Christian in nature. For example, on March 20, 1978, the Chaplain gave the following invocation: "Father in heaven, the suffering and death of your son brought life to the whole world moving our hearts to praise your glory. The power of the cross reveals your concern for the world and the wonder of Christ crucified." Id. at 823 n.2 (Stevens, J., dissenting).

${ }^{26} I d$. at 786.

${ }^{27}$ See id. at 787. 
the Establishment Clause: "Clearly the men who wrote the First Amendment Religion Clauses did not view paid legislative chaplains and opening prayers as a violation of that Amendment, for the practice of opening sessions with prayer has continued without interruption ever since that early session of Congress. ${ }^{28}$ The Court assumed that the incongruity was recognized and reconciled by Congress when it was adopted: "[T] he Senate reasoned that since prayer was said by the very Congress that adopted the Bill of Rights, the Founding Fathers could not have intended the First Amendment to forbid legislative prayer or viewed prayer as a step toward an established church. ${ }^{29}$

The Marsh majority's reasoning relied on the weight of history, tradition, and original intent. The opinion conceded that history was not mandatory authority for contemporary adjudication, but argued that the actions of the Framers should be accorded more weight than mere historical authority:

Standing alone, historical patterns cannot justify contemporary violations of constitutional guarantees, but there is far more here than simply historical patterns. In this context, historical evidence sheds light not only on what the draftsmen intended the Establishment Clause to mean, but also on how they thought that Clause applied to the practice authorized by the First Congress-their actions reveal their intent. An Act "passed by the first Congress assembled under the Constitution, many of whose members had taken part in framing that instrument,... is contemporaneous and weighty evidence of its true mean-

By assuming that original intent was properly inferred and interpreted by the first Congresses, the Marsh Court avoided the burden of further analysis. ${ }^{31}$

The majority assessed the actual practice of legislative prayer, but determined that no feature violated the Establishment Clause since each was consistent with historical tradition. ${ }^{32}$ Although the Eighth Circuit had objected to the governmental selection of a clergy member from a single denomination, ${ }^{33}$ the Supreme Court remained untroubled by a potential endorsement of a single religion: "We cannot,

${ }^{28}$ Id. at 788 .

${ }^{29}$ Id. at 789 n.10.

${ }^{30} I d$. at 790 (omission in original) (quoting Wisconsin v. Pelican Ins. Co., 127 U.S. 265, 297 (1888)).

${ }^{31}$ Although the majority noted that the Eighth Circuit applied the Lemon analysis, it declined to do the same. See id. at 786.

${ }^{32}$ See id. at 793-94.

${ }^{33}$ See Chambers v. Marsh, 675 F.2d 228, 234 (8th Cir. 1982). 
any more than Members of the Congresses of this century, perceive any suggestion that choosing a clergyman of one denomination advances the beliefs of a particular church. ${ }^{\text {34 }}$ In addition, the Court held that compensating a chaplain with federal tax dollars did not violate the First Amendment, since that "remuneration is grounded in historic practice. ${ }^{95}$ In spite of the Supreme Court's Establishment Clause jurisprudence that had evolved from Everson to Lemon, the Court in Marsh declined the opportunity to apply modern tests and relied instead on historical tradition.

The Marsh opinion is significant for several reasons, particularly as it impacts on the Court's practice of secularization. First, the opinion is clear evidence that the Court is willing to look beyond the language of the Establishment Clause in order to ascertain whether or not practices are constitutional. In addition, and perhaps more significantly, the opinion indicates the degree to which the Supreme Court understands certain religious practices and symbols to be integral to American history and tradition. In the contexts of public displays and national invocations, the Court invokes the weight of history. But history, in these later opinions, has a dual function. It is employed as evidence of original intent, as in Marsh, and it is understood as a vehicle for altering the religiousness of certain practices and symbols.

\section{Secularization-Public Displays}

During the 1980s, the Supreme Court decided Lynch v. Donnelly ${ }^{36}$ and County of Allegheny $v$. ACLU, applying theories of secularization in both decisions. In Lynch, the Court reversed the First Circuit and held that a crèche, a three dimensional representation of the birth of Christ, erected by the City of Pawtucket, Rhode Island, as part of a display also featuring a Santa Claus, a Christmas tree, and a "Seasons Greetings" sign, did not violate the Establishment Clause. ${ }^{88}$ The Lynch Court relied heavily on history and tradition in holding that the crèche, displayed on government property, was not sufficiently religious to violate the Establishment Clause. The Court applied the

\footnotetext{
${ }^{\text {s4 }}$ Marsh, 463 U.S. at 793.

35 Id. at 794.

${ }^{36} 465$ U.S. 668 (1984).

${ }^{37} 492$ U.S. 573 (1989).

${ }^{29}$ See Lynch, 465 U.S. at 687.
} 
Lemon test, and found that, "in the context of the Christmas season," "99 the crèche fulfilled the valid secular purpose of celebrating the holiday. ${ }^{40}$ Furthermore, any benefit to a specific faith, or to religion in general, was remote or incidental, and therefore did not advance religion. ${ }^{41}$ In addition, the crèche created no administrative entanglement since the government did not consult church authorities in assembling the display, ${ }^{42}$ nor did it spend a consequential amount of money maintaining the display. ${ }^{43}$

Although the Court applied the Lemon test to the facts of Lynch, each prong of the test was analyzed in light of history and tradition. ${ }^{4}$ Thus, in the context of the Christmas display, the crèche was not sufficiently religious to violate any prong of the Lemon test. ${ }^{45}$ Furthermore, the Court analyzed the crèche relative to other religious symbols and practices-both those unchallenged and those previously upheld-and found that invalidating the crèche would be inconsistent with social norms:

It would be ironic, however, if the inclusion of a single symbol of a particular historic religious event, as part of a celebration acknowledged in the Western World for 20 centuries, and in this country by the people, by the Executive Branch, by the Congress, and the courts for 2 centuries, would so "taint" the city's exhibit as to render it violative of the Establishment Clause. To forbid the use of this one passive symbol-the crèche-at the very time people are taking note of the season with Christmas hymns and carols in public schools and other public places, and while the Congress and legislatures open sessions with prayers by

Id. at 679 .

10 See id. at 676 (noting that Christmas was recognized as a national holiday and, therefore, its celebration was sufficiently secular). Justice O'Connor wrote a separate concurring opinion advocating an endorsement standard which would inquire whether a reasonable observer would interpret the crèche as a government endorsement of religion. In light of the context of the display, Justice O'Connor argued that a reasonable observer would not perceive the crèche as an endorsement of any particular religion, or of religion over irreligion. See id. at 690-94 (O'Connor, J., concurring).

${ }^{4}$ See id. at 683. Again, the Court relied on the congressional recognition of Christmas as a national holiday to hold that the crèche did not advance religion any more "than the Congressional and Executive recognition of the origins of the Holiday itself, as 'Christ's Mass,' or the exhibition of literally hundreds of religious paintings in governmentally supported museums." Id.

${ }^{12}$ See id. at 684 . The Court did not reach the issue of whether the crèche caused entanglement through political divisiveness since divisiveness was no longer sufficient to establish entanglement. See id. at 684-85.

${ }^{43}$ See id. at 684 (noting the de minimis value of the "tangible material" of the crèche).

14 See id. at 674-78.

15 See id. at 685. 
paid chaplains, would be a stilted overreaction contrary to our history and to our holdings.

The opinion explicitly rested its holding on the finding that holiday crèches are no more or less palatable than many other religious symbols. ${ }^{47}$ Thus, the Court declined the opportunity to assess the crèche independent of the existence of other types of potentially violative symbols. Indeed, the Court seemed to fear that invalidating the crèche would jeopardize other commonly accepted symbols and practices, and the opinion implied that the Court was unprepared to embark on such a politically unattractive task. The majority opinion cautioned that "[i]f the presence of the crèche in this display violates the Establishment Clause, a host of other forms of taking official note of Christmas, and of our religious heritage, are equally offensive to the Constitution. ${ }^{48}$ The hesitation expressed by the Court is not unwarranted: Many other practices and symbols would be jeopardized if the Court had held that the crèche violated the Establishment Clause. Though this would present a daunting task for courts, it is an unsatisfying justification for upholding the constitutionality of otherwise violative practices and symbols.

The Court considered the constitutionality of public displays again in County of Allegheny v. ACLU, ${ }^{49}$ but under significantly different factual circumstances than in Lynch. In Allegheny, the City of Pittsburgh allowed a crèche to be placed on the Grand Staircase of the Allegheny County Courthouse, and a menorah, a candelabrum which is used as part of the Jewish festival of Chanukah, to be erected outside the City-County Building. The crèche was donated by a Roman Catholic group. A sign posted with the display indicated its sponsor, and a banner read "Gloria in Excelsis Deo!" phernalia accompanied the crèche. In contrast, the menorah was part of a larger display, including a Christmas tree and a sign declaring the city's "salute to liberty. ${ }^{51}$ There was no consensus in the Allegheny decision regarding either the appropriate method of analysis or the constitutionality of the crèche and the menorah.

\footnotetext{
${ }^{46}$ Id. at 686 .

${ }^{17}$ See id. at 685-86.

49. at 686 .

492 U.S. 573 (1989).

${ }^{50} I d$. at 580 ("Glory to God in the Highest").

${ }^{51} \mathrm{Id}$. at 582.
} 
The Court held that the crèche violated the Establishment Clause, but the display of the menorah was constitutional..$^{52}$ Justice Blackmun, joined by Justices Brennan, Marshall, Stevens, and O'Connor, applied the endorsement standard articulated by Justice O'Connor in Lynch, in which she defined impermissible endorsement as any government message that may be perceived as favoring adherents or excluding nonadherents from the political community. ${ }^{53}$ The Court held that the Establishment Clause forbids "government from appearing to take a position on questions of religious belief or from 'making adherence to a religion relevant in any way to a person's standing in the political community." ${ }^{54}$ Furthermore, the Court emphasized that the endorsement inquiry necessarily requires evaluation of the context of a challenged practice or symbol..$^{55}$ The Court in Allegheny found that, in contrast to the context of the crèche in Lynch, because the crèche at the Pittsburgh Courthouse stood alone, without secular symbols or messages, it was likely to be perceived as an endorsement of religion: ${ }^{56}$ "Here, unlike in Lynch, nothing in the context of the display detracts from the crèche's religious message.... $[\mathrm{I}] \mathrm{t}$ is the single element of the display on the Grand Staircase." The opinion distinguished the secular acknowledgment of Christmas allowed in Lynch from a truly Christian celebration, reiterating that the former was permissible but providing little explanation for this apparent logical incongruity. ${ }^{58}$

The five Justices holding that the crèche violated the Establishment Clause divided on the constitutionality of the menorah. Justices Brennan, Marshall, and Stevens believed that the menorah also failed

52 See id. at 579 (plurality opinion).

${ }^{53}$ See id. at 592-95.

${ }^{54}$ Id. at 594 (quoting Lynch v. Donnelly, 465 U.S. 668, 687 (1984) (O'Connor, J., concurring)).

${ }^{55}$ See id. at 598 (" $[\mathrm{N}]$ othing in the context of the display detracts from the crèche's religious message."); see also id. at 595 (plurality opinion) ("[W]hether the government's use of an object with religious meaning has the effect of endorsing religion.... turns upon the context in which the contested object appears ....").

${ }^{56}$ The Court noted that the crèche was accompanied by several poinsettia plants. However, the Court found that rather than conveying a secular message, the plants merely created a frame around the crèche. The flowers "serve[d] only to draw one's attention to the message inside the frame." Id. at 599.

${ }^{57}$ Id. at 598.

${ }^{58}$ See id. at 601 ("The government may acknowledge Christmas as a cultural phenomenon, but under the First Amendment it may not observe it as a Christian holy day by suggesting that people praise God for the birth of Jesus."). 
the endorsement test. ${ }^{59}$ However, Justices Blackmun and O'Connor upheld the menorah under the endorsement test and achieved a majority for this holding by gaining the support of Chief Justice Rehnquist and Justices White, Scalia, and Kennedy. The latter four Justices rejected the endorsement test and found both the crèche and the menorah constitutional by applying a less rigorous inquiry. ${ }^{60}$ Indeed, the result reached by Justices Blackmun and O'Connor seems incongruous: How could the crèche offend the Establishment Clause while the menorah did not? Although Justice Blackmun's opinion conceded that a menorah is a religious symbol, the context of the display was sufficient to assuage fears that a reasonable observer would perceive it as an endorsement of religion. According to Justice Blackmun, " $[t]$ he necessary result of placing a menorah next to a Christmas tree is to create an 'overall holiday setting' that represents both Christmas and Chanukah-two holidays, not one. ${ }^{\text {"61 }} \mathrm{He}$ explained that because both holidays were being celebrated as "secular holidays," the menorah did not violate the Establishment Clause. ${ }^{62}$ Furthermore, Justices Blackmun and O'Connor supported their interpretation by arguing that the banner saluting liberty which accompanied the menorah neutralized any potential religious message. ${ }^{63}$ As in Lynch, context transformed the religious symbol into a secular object.

The lack of consensus among the Justices, as well as the seemingly inconsistent results of Lynch and Allegheny, make it difficult to distill any coherent rule from these cases. Yet the opinions do stand for one discernible proposition: Where a practice or symbol is perceived as integral to American culture, or where the context of a display which

${ }^{39}$ See id. at 637 (Brennan, J., dissenting) (disputing the notion that the display of the menorah "shows no favoritism towards Christianity, Judaism, or both").

${ }^{60}$ See id. at 679 (Kennedy, J., concurring in the judgment in part) (arguing that "we have no jurisdiction over matters of taste within the realm of constitutionally permissible discretion").

${ }^{61}$ Id. at 614 (plurality opinion) (quoting Lynch v. Donnelly, 465 U.S. 668, 692 (1984) (O'Connor, J., concurring)).

${ }^{62}$ Id. at 615 (plurality opinion). According to Justice Blackmun, Christmas trees are not religious symbols and therefore do not offend the Establishment Clause: "The Christmas tree, unlike the menorah, is not itself a religious symbol. Although Christmas trees once carried religious connotations, today they typify the secular celebration of Christmas." Id. at 616 (plurality opinion).

${ }^{63}$ See id. at 619 (plurality opinion). The banner read: "During this holiday season, the city of Pittsburgh salutes liberty. Let these festive lights remind us that we are the keepers of the flame of liberty and our legacy of freedom." Id. at 635 (O'Connor, J., concurring). 
includes religious articles creates an impression of mere holiday celebration or religious pluralism, the symbols will be recharacterized as secular.

\section{Secularization-National Invocations}

The Supreme Court has also participated in the secularization of religious references in national mottoes and recitations with little hesitation. Indeed, Court opinions have supported more controversial instances of secularization by referencing the commonly accepted invocation of religious sentiments in the Pledge of Allegiance or on coins. ${ }^{64}$ This type of invocation rarely has been challenged, and the Supreme Court has declined to review such cases that have reached the courts of appeals. ${ }^{65}$

Federal courts of appeals have adopted the Supreme Court's language of secularization, upholding the invocation of religious symbols and practices by the state. ${ }^{66}$ In Sherman v. Community Consolidated School District 21, the Seventh Circuit held that the recitation of the Pledge of Allegiance by teachers and willing students did not violate the Establishment Clause, in spite of the language "under God." Employing the same reliance on history and original intent adopted by the Supreme Court in the public prayer and display cases, the Seventh Circuit reasoned that because the Framers engaged in public invocations of religious terms and symbols, they must not have contemplated such uses as an "establishment" of religion. ${ }^{68}$ Furthermore,

See cases cited supra note 3.

${ }^{65}$ See, e.g., Sherman v. Community Consol. Sch. Dist. 21, 508 U.S. 950 (1993), denying cert. to 980 F.2d 437 (7th Cir. 1992) (allowing recitation of the Pledge of Allegiance in a public school as long as students were free not to participate).

${ }^{60}$ See, e.g., Cammack v. Waihee, 932 F.2d 765 (9th Cir. 1991) (holding that the declaration of Good Friday as a public holiday in Hawaii did not violate the Establishment Clause).

${ }^{67} 980$ F.2d at 439 . The Supreme Court previously had held that compulsory avowals of faith to any religious or national symbol were unconstitutional. See West Va. State Bd. of Educ. v. Barnette, 319 U.S. 624, 642 (1943) ("[N]o official, high or petty, can prescribe what shall be orthodox in politics, nationalism, religion, or other matters of opinion or force citizens to confess by word or act their faith therein."). In Sherman, the Seventh Circuit held that the Pledge itself did not violate the Establishment Clause, despite possible pressure to participate on students who chose to remain silent. See 980 F.2d at $443-44$.

is See Sherman, 980 F.2d at 445-46 ("James Madison ... issued presidential proclamations of religious fasting and thanksgiving. Thomas Jefferson, who refused on separationist grounds to issue thanksgiving proclamations, nonetheless signed treaties sending ministers to the Indians." (footnote omitted)). 
the court unequivocally distinguished this type of reference from the one prohibited by the Supreme Court in Allegheny, stating that "'there is an obvious distinction between crèche displays and references to God in the motto and the pledge." ${ }^{69}$ Although this distinction may be obvious to the court of appeals, such a conclusory statement does not provide any meaningful explanation. Is such a distinction between a representation of the birth of Christ and a profession of allegiance to "one nation under God" obvious to school children or to atheists?

Cases legitimizing public displays and national invocations of religion rely, to varying degrees, on the proposition that religiousness is a contextual label: Whether a symbol or practice is religious depends on context and history. Symbols and practices which were at one time religious can lose their religious significance (for purposes of constitutional analysis) when surrounded by nonreligious items or when consistently included in national celebrations over the course of history. According to this theory, history, time, and culture somehow diminish or erase the religious import of practices and symbols which continue to be used and invoked by religion.

\section{B. Critiquing the Logic of Secularization Analysis}

The secularization of religious practices and symbols by the Supreme Court, followed by lower courts, has become a customary means of preserving religious references that the general public (or at least the courts) find agreeable. However, the reasoning employed in these opinions, and their heavy reliance on history, are problematic. While historical practice is often examined in constitutional adjudication, it has limited relevance in the Establishment Clause context.

${ }^{69}$ Id. at 447-48 (quoting County of Allegheny v. ACLU, 492 U.S. 573, 603 (1989)). Many separationist scholars also subscribe to this distinction. See, e.g., Kenneth L. Karst, The First Amendment, the Politics of Religion and the Symbols of Government, 27 HARV. C.R.-C.L. L. REV. 503, 520-21 (1992) (asserting that references to God in this context are acceptable under any foreseeable Establishment Clause analysis); Kathleen $M$. Sullivan, Religion and Liberal Democracy, 59 U. CHI. L. REV. 195, 207-08 n.59 (1992) ("Rote recitation of God's name is easily distinguished as a de minimis endorsement in comparison with prayer or the seasonal invocation of sacred symbols."). 


\section{The Limited Relevance of History}

Judges often rely on history in constitutional jurisprudence. In the current context, however, the Court carries historical analysis a step further by asserting that endurance results in an epistemological transformation. This reasoning relies on the assumption that mere longevity alters the meaning of such invocations. As one scholar has noted, this logic renders "the Establishment Clause unintelligible by substituting historical citation for principled adjudication. ${ }^{.70}$ By privileging history over contemporary legal reasoning, the Court eviscerates the potency of the Establishment Clause as a protection of both church and state.

As many critics of the Marsh decision have noted, Establishment Clause analyses constructed on arguments about original intent are dubious. ${ }^{71}$ Even assuming that history is sufficient to dictate modern jurisprudence, the Court's reliance on the rationale and behavior of eighteenth-century lawmakers is misplaced. ${ }^{72}$ The meaning and purpose of the Establishment Clause have changed with the social evolution of the nation. Furthermore, the circumstances under which the religion clauses were adopted indicate that the Clauses emerged in response to particular local concerns ${ }^{73}$ and were included in the First Amendment at the insistence of local-rather than congressional-

${ }^{70}$ Hall, supra note 13 , at 47.

${ }^{71}$ See, e.g., id.; Michael M. Maddigan, The Establishment Clause, Civil Religion, and the Public Church, 81 CAL. L. REv. 293, 307 (1993) (describing the Court's reliance on history in Marsh as a "poor" method "because it sheds no light on the meaning of, or principle behind, the Establishment clause"); Yehuda Mirsky, Civil Religion and the Establishment Clause, 95 YALE L.J. 1237, 1245-46 (1986) (criticizing the Marsh decision as "unprincipled").

${ }_{72}$ Whether or not original intent is a valid and determinative means of interpreting the religion clauses, the Supreme Court should not merely study the behavior of the First Congress. As Professor Hall argues, the Constitution itself is "godless," giving "some indication that the Framers treated normal politics differently from constitutional politics and that we should not rush to make normal politics the divining rod for discerning constitutional meaning." Hall, supra note 13, at 49; see also ISAAC KRAMNICK \& R. LAURENCE MOORE, THE GODLESS CONSTITUTION $26-45$ (1996) (chronicling the debates after the omission of God in the Constitution); LEO PFEFFER, CHURCH AND STATE FREEDOM 240 (rev. ed. 1967) (noting that the omission of reference to God in the Constitution was intentional rather than inadvertant and, thus, should certainly not be cited as a reason for holding governmental invocations constitutional).

${ }^{73}$ See ThOMAS J. CURRY, THE FIRST FREEDOMS: CHURCH AND STATE IN AMERICA TO THE PASSAGE OF THE FIRST AMENDMENT 198-99 (1986) ("Just getting elected to Congress had proved difficult for [Madison].... Once elected, however, Madison ... informed the House that he considered himself "bound in honor and in duty' to present and advocate amendments."). 
activists who feared intrasect discrimination. ${ }^{74}$ The First Amendment thus was adopted with little anticipation of its implications when interpreted by the courts: "When the First Congress debated various versions of the present First Amendment, they focused on style rather than substance and never inquired how the amendment would affect particular controversies. ${ }^{75}$ In light of the context of the adoption of the Establishment Clause, it seems unreasonable to infer that members of the First Congress recognized the incongruity of their actions with the recently passed Amendments. One scholar compares the practices of the First Congress with those of the Reconstruction Congress:

The willingness of the First Congress to have President Washington facilitate a prayerful republic should no more control the meaning of the Establishment Clause than the willingness of the Reconstruction Congress to educate black children in segregated and inferior schools should control the Fourteenth Amendment's Equal Protection Clause. In both cases, lawmakers introduced a new principle within constitutional discourse. They did not ponder the varied ways in which that principle might work out in practice ....

Current reliance on the actions of the Framers imputes to them a degree of awareness and conscience that most likely did not exist at the time.

\section{Misapplication of History}

In addition to creating results which probably were unintended by the Framers, dependence on historical practice is thoroughly inadequate to address contemporary conflicts of church and state. Secularization analysis cites history not only as evidence of original intent, but also as an essential element for expunging religious import. In order to assert comfortably that a practice has "lost its religious significance, ${ }^{n 7}$ however, the Court assumes a level of understanding and familiarity with American culture that many citizens and visitors do not possess. Indeed, a child reciting the Pledge of Allegiance for the first time probably does not have the requisite historical knowledge to understand that swearing an oath to "one nation under God" is not a pronouncement of religious faith. Fur-

\footnotetext{
${ }^{74}$ See id. at 189 (describing the fears of Virginia Baptists).

${ }^{75}$ Hall, supra note 13 , at 48 .

${ }^{76}$ Id. (footnote omitted).

${ }^{7}$ Lynch v. Donnelly, 465 U.S. 668, 675 (1984).
} 
thermore, it is inappropriate for the Court to function in this way, as an arbiter of cultural semiotics. As the ultimate interpreter of the secular law, the Supreme Court should not undertake the delicate task of ascertaining whether the presence of a life-size plastic Santa Claus mitigates the religiousness of a three-dimensional representation of the birth of Jesus Christ.

Historical longevity does not adequately justify the Supreme Court's attempts to expunge religion from practices and symbols once commonly acknowledged as religious. Yet the Court is not alone in its efforts to legitimize a marriage of church and state in religious displays, public prayer, and national invocations. As discussed in Part III, many scholars also strive to preserve religion in the public sphere, relying on the concept of "civil religion" to explain and justify secularization.

\section{AMERICAN CIVIL RELIGION}

The concept and language of secularization was not created by the Supreme Court, but was adapted from academic discourse and the notion of "civil religion." Sociologist Robert Bellah first articulated the concept of civil religion as a collection of values, ideals, symbols, and rituals derived from common experience which unify people in loosely affiliated social structures. ${ }^{78}$ Since its introduction, however, the concept of civil religion has been reinterpreted, and many modern scholars now understand civil religion to include elements of sacral religion, forming a set of secular and religious norms universally accepted in American society. ${ }^{79}$ As this Part will demonstrate, Supreme Court church and state doctrine has continually invoked notions derived from civil religion, particularly in the secularization of religious symbols and practices. ${ }^{80}$ However, the Su-

${ }^{78}$ See Robert N. Bellah, Civic Religion in America, 96 Dedalus 1, 5 (1967) (describing the development of the notion of civil religion).

${ }^{79}$ See, e.g., Will Herberg, America's Civil Religion: What It Is and Whence It Comes, in AMERICAN CIVIL RELIGION 76, 76-77 (Russell E. Richey \& Donald G. Jones eds., 1974) (describing the existence of common values); Maddigan, supra note 71, at 304 (suggesting that the Court has wrongly disregarded sociological effects of religion on Americans); Mirsky, supra note 71, at 1239 (arguing that the Supreme Court should acknowledge America's civil religion).

${ }^{80}$ See generally County of Allegheny v. ACLU, 492 U.S. 573 (1989) (allowing some religious displays on the ground that the symbols are secular in context); Lynch $v$. Donnelly, 465 U.S. 668 (1984) (holding that a city erecting a crèche did not violate the Constitution); Marsh v. Chambers, 463 U.S. 783 (1983) (holding that opening state 
preme Court has been capricious in its references to civil religion; although Court opinions have alluded to vague notions of civil religion, none have discussed the doctrinal or social implications of employing it as support for secularization.

\section{A. Defining Civil Religion}

\section{The Incarnation of Civil Religion}

Civil religion is generally understood as a natural compilation of "values, symbols, rituals and metaphysical assumptions" ${ }^{\text {"81 }}$ that evolved as a societal response to the chaos and lack of social order associated with the advent of modernity. ${ }^{82}$ Bellah understood the emergence of civil religion as a means of achieving social order in a society that was undergoing rapid change. As one scholar explains, "[b]y developing and nurturing civil religions the members of modern societies attempt to recapture some of the lost, organic solidarity of pre-modern societies by linking political ideas and institutions, naturally shared by all, with a network of hallowed meanings." ${ }^{83}$ According to this theory, civil religion provides a secular set of norms and values formerly shared by a society that was homogeneous and united religiously, economically, and socially.

Although civil religion as it was initially envisioned by Bellah was derived in part from elements of traditional theistic religions, ${ }^{84}$ the compilation of the ideas, values, symbols, and rituals is political rather than sacral. ${ }^{85}$ Bellah conceived of civil religion as a social structure fully distinct from religion, ${ }^{86}$ although many elements of American civil religion were derived from Puritanism and the Jewish and Christian traditions. ${ }^{87}$ Furthermore, Bellah's civil religion does not attempt

legislative sessions with a Christian prayer by a chaplain does not violate the Establishment Clause).

${ }^{81}$ Mirsky, supra note 71, at 1248 (citing Bellah, supra note 78, at 1).

${ }^{82}$ See id. at 1249.

8 Id. at 1250.

${ }^{84}$ See id. at 1248.

${ }^{85}$ See id. at 1249.

${ }^{86} \mathrm{See}$ Bellah, supra note 78, at 1 (describing civil religion as existing "alongside of and rather clearly differentiated from the churches"); see also Deborah $\mathrm{K}$. Hepler, The Constitutional Challenge to American Civil Religion, KAN. J.L. \& PUB. POL'Y, Winter 1996, at 93, 96 .

${ }^{87}$ See Mirsky, supra note 71, at 1251. 
to usurp the explicative and didactic functions of sacral religions. ${ }^{88}$ Rather, it unites citizens, regardless of their religious convictions, in a structure which is ultimately political. Significantly, it is "free of overspecific symbols that exclude those who do not share in their meanings. ${ }^{89}$

\section{Modern Interpretations of Civil Religion}

Although Bellah articulated civil religion as a political rather than a sacral concept, modern scholars have interpreted contemporary American civil religion as embodying varying degrees of traditional sacral religion. ${ }^{90}$ These discrepancies are not trivial. The degree to which scholars, and more importantly, the Supreme Court, understand civil religion as a sacral concept drastically affects the categorization of symbols and practices as religious or secular. For example, some modern scholars argue that the concept of "God," albeit in what they claim is a universal sense, is inherent in civil religion. ${ }^{91}$ This construction of civil religion secularizes the word, if not the concept, resulting in an invocation of God which ostensibly "does not threaten the religious liberty contemplated by the Establishment Clause. ${ }^{\prime 2}$

Others draw the inference that the existence of civil religion necessarily legitimizes commonly accepted practices that have their foundations in sacral religions. ${ }^{93}$ A theory of civil religion that incor-

${ }^{83}$ See Maddigan, supra note 71 , at 325 ("Americans... embrace both the civil religion and involvement in more traditional churches, seeing, for the most part, no conflict between the two."); see also id. at 327 (distinguishing the "civil society" activities of traditional religions, which are paralleled in civil religion, from the "theologically religious" activities, which are not).

${ }_{99}$ Hepler, supra note 86, at 106. Examples of elements of Bellah's civil religion include Memorial Day, the Fourth of July, presidential birthdays, and the flag. See id. at 97.

so See, e.g., Janet L. Dolgin, Religious Symbols and the Establishment of a National "Religion", 39 MERCER L. REV. 495, 505 (1988) (asserting that civil religion, as understood by the Court, is fundamentally a political interpretation of Christianity); Maddigan, supra note 71, at 320-21 (emphasizing the significance of the Bible in American civil religion).

${ }^{91}$ See, e.g., Maddigan, supra note 71, at 322-28 (discussing the role of "God" in America's public life); Marjorie A. Silver, Rethinking Religion and Public School Education, 15 QLR 213, 213 (1995) (describing the United States as "a nation founded on a tradition of a theistic civil religion").

${ }_{92}$ Maddigan, supra note 71 , at 326.

${ }^{93}$ See Jimmy Daniels, The First Amendment: Has the Supreme Court Overlooked Its Role As Guardian of Our Freedom by Failing to Distinguish Between Real Threat and Mere Shadow?, 46 MERCER L. REV. 1167, 1185-87 (1995) (concluding that many practices rooted in 
porates elements of sacral religion, rather than maintaining an essentially political character, affords great latitude for institutional secularization of religion. In effect, it legitimizes government religious practices by carving out a poorly defined sphere where religious practices are disguised as secular ones by the cloak of civil religion. According to this logic, "the Court should have recognized that the Marsh prayers do not violate the First Amendment because they do not involve theological religion at all. Instead, they exemplify American civil religion. ${ }^{\text {"94 }}$ If civil religion includes sacral religious concepts, then government adoption and secularization of these concepts is easily justified.

\section{B. Civil Religion As a Legal Justification for Secularization}

The Supreme Court has never explicitly acknowledged the concept of civil religion per se, but by stating that practices and symbols have lost religious significance or are steeped in tradition and history, the Court is relying on a nebulous incarnation of civil religion. ${ }^{95}$ Whether civil religion is defined as purely political or as influenced by sacral religion is a significant distinction in the context of purely cultural debate. Neither construction, however, justifies any reliance on civil religion by the Supreme Court. The mere existence of civil religion as a social phenomenon does not mean that it should be sanctioned by government institutions.

Advocates of the use of civil religion in Supreme Court adjudication support the measuring of challenged practices against acceptable practices and symbols permitted by civil religion: "By recognizing the phenomenon of civil religion in establishment clause adjudication, courts can make better sense of existing public religion and avoid undue and constitutionally illegitimate inferences from civil religion to traditional, sacral religion." ${ }^{, 96}$ This view assumes that retaining public religion is desirable-and that civil religion is an acceptable basis for constitutional jurisprudence. Civil religion might suffice as a

Christianity do not endorse a particular faith because they are part of American civil religion).

Maddigan, supra note 71, at 338.

${ }^{95}$ See Hepler, supra note 86, at 108 (asserting that " [w] henever the Court acknowledges that a religious practice is 'part of the fabric of society', it is acknowledging what sociologists call civil religion" (quoting Marsh v. Chambers, 463 U.S. 783, 792 (1983))).

${ }^{96}$ Mirsky, supra note 71 , at 1255. 
benchmark for adjudication if it was known beyond ivory towers and unanimously understood as a political doctrine, rather than as a vague and variously interpreted notion of a unification of religion, social norms, and politics. However, because it is not widely understood by legal scholars and is hotly contested, it is an inappropriate tool for constitutional adjudication. ${ }^{97}$

Civil religion is a poor explanation for the Supreme Court's practice of secularization, and an inadequate justification for the policy. While the academic exercise is merely unsatisfying, the practical application of secularization has had unfortunate consequences. Potential justifications for secularization are rendered ineffectual in the face of the actual and very damaging consequences of the practice.

\section{THE DETRIMENTAL EFFECTS OF SECULARIZATION}

Secularization which derived from a legally sanctioned, albeit nebulous, civil religion determined the outcome of Marsh, Lynch, Allegheny, and Sherman, and it continues to influence church and state doctrine. Although the Supreme Court's application of these concepts has gone largely unnoticed by the general public, secularization has severe consequences for religion, government, and the individual. Constitutional scholar William Van Alstyne described this phenomenon as

a movement from one national epigram to another; it is the movement from 'E Pluribus Unum' to 'In God We Trust,' from the ideal expressed by our original Latin motto-one nation out of highly diverse but equally welcome states and people-to an increasingly pressing enthusiasm in which government re-establishes itself under distinctly religious auspices.

This Part seeks to demonstrate that although characterization of religious practices and symbols as secular may preserve traditions that are agreeable to a subset, or even a majority of the public, it threatens the integrity of both religion and government, and ultimately marginalizes nonadherents.

${ }^{97}$ See Hepler, supra note 86, at 113 ("Courts ... should not borrow [civil religion] from sociologists to bolster their reasoning when adjudicating First Amendment cases. . . By employing the concept of civil religion, courts give it legal significance, which would encourage an Establishment Clause challenge to its existence.").

${ }^{98}$ William Van Alstyne, Trends in the Supreme Court: Mr. Jefferson's Crumbling Wall-A Comment on Lynch v. Donnelly, 1984 DUKE L.J. 770, 771. 


\section{A. Detriment to Religion}

\section{Government Encroachment on Religious Autonomy}

In Everson, the Supreme Court articulated several critical functions of the Establishment Clause. Among these, the preservation of the integrity of religion was crucial. The Court stressed that " $[t]$ he structure of our government has ... secured religious liberty from the invasion of the civil authority." ${ }^{99}$ The protection of religion from state interference has been heralded as a great benefit of the religion clauses since their inception. For example, after interviewing clergy and members of many religious faiths, Alexis de Tocqueville noted that "they mainly attributed the peaceful dominion of religion in their country to the separation of Church and State. ${ }^{\$ 100}$ In order to preserve this harmony, religion must be independent from even the most benign influences of government, for if the state may aid or coopt religion, it may also regulate it. ${ }^{101}$

Classification by the Court does a great disservice to religion when it pronounces that holidays or symbols of a given religious group are secular. Characterizing a crèche, which symbolizes the origins of Christianity, as merely "engender[ing] a friendly community spirit of good will in keeping with the season, ${ }^{102}$ may constitute blasphemy for faithful observers. ${ }^{103}$ Similarly, although the Court in Marsh may have considered its decision a means of preserving tradition, one scholar has noted that " $[\mathrm{i}] \mathrm{t}$ would, no doubt, come as a surprise to those who offer legislative prayers that their efforts are constitutional only because the Court construes their words to be the functional equivalent of the gavel used to bang a meeting to order. ${ }^{104}$ The Court dilutes or

${ }^{99}$ Everson v. Board of Educ., 330 U.S. 1, 15 (1947) (quoting Watson v. Jones, 80 U.S. (13 Wall.) 679, 730 (1871)).

${ }^{100} 1$ ALEXIS DE TOCQUEVILIE, DEMOCRACY IN AMERICA 313-14 (Henry Reeve trans., Colonial Press 1900) (1831), quoted in Robert S. Peck, The Threat to the American Idea of Religious Liberty, 46 MERCER L. REV. 1123, 1136 (1995).

${ }_{101}$ See Everson, 330 U.S. at 27 (Jackson, J., dissenting) (arguing that the Constitution prohibits making public business out of religious activity).

${ }^{102}$ Lynch v. Donnelly, 465 U.S. 668, 685 (1984).

${ }^{103}$ Even those who might be perceived as beneficiaries of the Court's refusal to eradicate Christian and Jewish traditions from the civic sphere recognize the problems inherent in such an approach. See, e.g., James M. Dunn, Neutrality and the Establishment Clause, in EQUAL SEPARATION: UNDERSTANDING THE RELIGION CLAUSES OF THE FIRST AMENDMENT 55, 60 (Paul J. Weber ed., 1990) (quoting the Reverend Billy Graham as saying, "[t]o tie the Gospel to any political system, secular program, or society is wrong and will only serve to divert the Gospel").

${ }^{104}$ Hall, supra note 13 , at 63 . 
entirely negates religious import, simultaneously insulting religion and imposing a watered-down version of religion on the general population. ${ }^{105}$

Not surprisingly, the response to this type of judicial secularization has not been uniformly positive. ${ }^{106}$ Justice Blackmun's plurality opinion in Allegheny describing the menorah as "simply a recognition of cultural diversity" ${ }^{107}$ was not well received by many Jews. ${ }^{108}$ Commentators also expressed regret at the secularization of Chanukah: " $[\mathrm{H}]$ aving found or created a sufficiently secular Christmas so that municipalities can do what they please, ... they apply the same procedure to Chanukah. ... But I dissent from the depths of my soul.... I want to keep my holidays full of holiness ...." ${ }^{109}$ One rabbi described a display permitted by Allegheny as "'an outrage.... [Hanukkah] is a religious holiday and by putting a menorah on public property we secularize Hanukkah." 110 By commenting on the authenticity and religiousness of symbols and practices, the Court interferes with the autonomy of religion, injuring the sanctity of religion and offending its members.

\section{Spiritual Pollution and the Violation of Voluntarism}

Judicial secularization of religious practices and symbols may offend religions which embrace tenets contrary to those embodied in the religion co-opted by the state. In order to avoid "spiritual pollution," "religious groups outside the mainstream, as interpreted by the majority, must divorce themselves from the general citizenry. Madison claimed that state support for Christianity would effectively

${ }^{105}$ See Hepler, supra note 86, at 94 (discussing the generality of American civil religion as a threat to traditional churches).

${ }^{106}$ See, e.g., Kaufman, supra note 6, at A15 (describing the Court's practice of determining the religiousness of challenged practices as "misguided substitution of assigned roles-jurist as spiritual mentor, legislator as itinerant preacher").

${ }_{107}$ County of Allegheny v. ACLU, 492 U.S. 573, 619 (1989) (plurality opinion).

${ }^{108}$ See, e.g., Jill Laurie Goodman, Creches, Menorahs, and the Courts, TIKkuN, Jan.-Feb. 1995, at 30, 30, available in 1995 WL 12580278 (noting that "because constitutional justifications for government-supported displays of religious imagery are found too often only by diminishing religion itself, people of faith ... . lose most").

${ }^{109}$ Id. at 85.

110 Bill Lindelof, Capitol Menorah Stirs Pride, Protest, SACRAMEnTo BEE, Nov. 27, 1994, at BI (quoting Rabbi Lester Frazin).

${ }^{111}$ Hall, supra note 13 , at 80 . 
"banish our Citizens." curs, it promotes the exclusion of those with conflicting beliefs. For instance, under Sherman, ${ }^{113}$ a nonadhering student would be forced to assert actively her minority status and remove herself from the classroom in order to avoid participation in swearing an oath to a deity other than her own. Children and adults confronting such a choice are forced to define themselves in opposition to their peers, and are similarly required to define themselves religiously, which may not comport with their personal identity. Although an individual may be an atheist and thus uncomfortable professing allegiance to God, that individual's atheism may not be the characteristic by which she chooses to assert her identity to others. Though her atheism may be fundamental, it may also be quite personal.

In other instances, separation in order to avoid spiritual pollution may not be possible. In Lynch and Allegheny, members of conflicting religions could avoid such pollution only by avoiding the public spaces where the crèches and menorah were located. ${ }^{114}$ Furthermore, the very existence of state-sponsored religious invocations, however sanitized by a declaration that they have "lost any true religious significance, ${ }^{, 15}$ pollutes the integrity of conflicting religions.

In addition to ostracizing groups with conflicting values, secularization establishes religion in general, and often the Jewish and Christian traditions, as the social norm. Under the guise of civic society, crèches, civic prayers, and the Pledge of Allegiance impute Christian mores and distort the pure voluntarism of religion. "Voluntarism'... mean[s] that religious societies are most genuine when their supporters arise from responding hearts and minds unassisted as well as undeterred by government. ${ }^{\text {116 }}$ Religion performs its

112 Id. (quoting JAMES MADISON, A MEMORIAL AND REMONSTRANCE (1785), reprinted in THE MiND OF THE Founder: SOURCES OF THE POLITICAL THOUghr OF JAMES MADISON 6, 11 (Marvin Meyers ed., rev. ed. 1981) [hereinafter THE MIND OF THE FOUNDER]).

${ }^{113}$ Sherman v. Community Consol. Sch. Dist. 21, 980 F.2d 437 (7th Cir. 1992) (discussed supra notes 67-69 and accompanying text).

${ }^{114}$ Although it is possible that a nonadherent could raise a free exercise claim by asserting that the displays interfered with her free exercise of religion, a court is likely to hold that mere exposure does not constitute a government-inflicted burden. See, e.g., Mozert v. Hawkins County Sch. Bd., 827 F.2d 1058, 1070 (6th Cir. 1987) (denying a free exercise claim when plaintiffs were not required to profess adherence or swear allegiance to any tenet or deity).

${ }_{115}$ Marsh v. Chambers, 463 U.S. 783, 818 (1983) (Brennan, J., dissenting).

${ }^{116}$ Carl H. Esbeck, A Restatement of the Supreme Court's Law of Religious Freedom: Coherence, Conflict, or Chaos?, 70 NOTRE DAME L. REV. 581, 625 (1995) (arguing that one 
functions of offering existential answers, as well as a sense of comfort, guidance, and community, only when an individual's adherence with the tenets is genuine. Government sanctioning of religious ideas effected by secularization distorts the genuineness of adherence: If God is a social fact rather than a spiritual choice, the belief of members may be a result of social conformance rather than individual conviction.

Ironically, although the Court seems to be straining its logic in order to preserve the inclusion of religious practices and symbols in secular society, it is effectively compromising religion. By asserting dominion over religion, the Court threatens the integrity of religion and jeopardizes the participation of religious groups in society, thereby disturbing the essential voluntarism of religious adherence. In spite of its benign intentions, the Court's jurisprudence treads heavily on the sanctity of religion.

\section{B. Detriment to Society}

Although secularization is often characterized as an "acknowledgment" of religion, ${ }^{117}$ putting the machinery of the state behind religion inevitably amounts to more than a mere "acknowledgment." Incorporation of religious icons into civic culture suggests that the government endorses the particular religion invoked. Furthermore, because secularized practices are most frequently those derived from Christianity, secularization privileges religion over irreligion, and Christianity over all. This consequence contributes to religious divisiveness, violating the fundamental principles behind the religion clauses. ${ }^{118}$

of the principle justifications for separationism is the desire to preserve the voluntary nature of citizens' religious choices).

${ }^{117}$ See, e.g., Lynch v. Donnelly, 465 U.S. 668, 677 (1984) (describing government declaration of a national day of prayer and Presidential Proclamations in honor of religious holy days as "acknowledgment"); Marsh, 463 U.S. at 792 (characterizing invocation of divine guidance on a public body as "a tolerable acknowledgment of beliefs widely held among the people of this country").

${ }^{118}$ Cf. MADISON, supra note 112, reprinted in THE MIND OF THE FOUNDER, supra note 112 , at 11 (condemning the Virginia Assessment Bill because it "will destroy that moderation and harmony which the forbearance of our laws to intermeddle with Religion, has produced amongst its several sects"). 


\section{The Myth of Mere Acknowledgment}

The crèches in Lynch and Allegheny and the frequent invocation of "God" in our mottoes and the Pledge have been deemed constitutional by the Court because they are classified not as establishments of religion, but as mere acknowledgments of a religiousness which has merged with our broader historical tradition. In Marsh, the Court upheld the legislative prayer because "it is simply a tolerable acknowledgment of beliefs widely held among the people of this country."119 Earlier, Justice Brennan, who dissented in Marsh, argued that invocations of God are not truly religious, but are mere references to our historical origins. ${ }^{120}$ According to this logic, "'One nation under God' becomes 'one nation that formerly deemed itself to be governed by overruling Providence." ${ }^{121}$

In spite of the Supreme Court's attempts to secularize religious practices and symbols by pronouncing them devoid of religious significance, it is clear that this logic fails in application. Instead of eliminating religion from the particular practice or symbol, the Court succeeds only in incorporating the religious sentiment into government. For instance, the Court's assertion in Lynch that the crèche was secular does not render it neutral in any sense; the crèche is no less Christian than it was before the Court's opinion. ${ }^{122}$ What may, to the members of the Court, be an innocent acknowledgment of religion may appear to individuals and religious groups as an official preference for one religion over all others. ${ }^{123}$ By officially incorporating elements of any single religion into civic culture, the government upsets the organic relationships existing among religious communities. Furthermore, the fact that the beliefs acknowledged are "widely held ${ }^{124}$ does not alleviate the tensions forged by such governmental

"19 Marsh, 463 U.S. at 792.

${ }^{120}$ See School Dist. of Abington Township v. Schempp, 374 U.S. 203, 304 (1963) (Brennan, J., concurring) ("The reference to divinity in the revised pledge of allegiance, for example, may merely recognize the historical fact that our Nation was believed to have been founded 'under God."').

${ }^{121}$ Hall, supra note 13, at 58.

${ }^{122}$ See Dolgin, supra note 90 , at 505 (arguing that the crèche “[s] till evok[es] centuries of Christian symbolism").

${ }^{123}$ See Hall, supra note 13, at 59 ("Government acknowledgment of particular religious beliefs-no matter how widely held-without a corresponding acknowledgment of alternative beliefs constitutes preferential treatment of the former over the latter.").

${ }^{124}$ Marsh, 463 U.S. at 792. 
sanction. ${ }^{125}$ Such acknowledgments naturalize majority religions, further marginalizing the spiritual ideals-or the absence of spiritual ideals - of the minority. Government necessarily privileges religion when it adopts its language or symbols, even those that are common to many sects.

\section{Privileging Religions and Fomenting Divisiveness}

The empowerment of religion, which necessarily results from government adoption of it under the guise of secularization, is destructive to the balance of religious and civic life, as well as to the relationships of religious groups to one another. Such implicit endorsements result in religious divisiveness and jeopardize the truly common culture that unites adherents of all religious sects and nonadherents. ${ }^{126}$

The threat posed to the integrity of religion similarly jeopardizes the cohesiveness of society. Individuals and religious groups are forced to isolate themselves, either by exempting themselves from secularized practices such as the Pledge or by withdrawing from civic functions to avoid spiritual pollution. Thus, secularization injures the civil community by forcing religious groups to choose between their religious and civil allegiances. ${ }^{127}$ Civil community suffers when subgroups insulate themselves; for when they do, "they no longer participate in the republican discourse concerning the common good.... and they may be more likely to doubt the legitimacy of law itself. ${ }^{128}$ The secularization of religion compels religious groups either to harmonize their own religious beliefs with those adopted by civic culture, or to reject civic culture and its requisite responsibilities in favor of religious purity. Supporters of the Court's secularization analysis would no doubt argue that exorcising religion from civic life com-

125 See Hall, supra note 13 , at 59 ("When government acknowledges the beliefs of a majority, the majority itself-operating through the governmental body-calls public attention to its own religious beliefs. These acknowledgments .... are assertions of power and dominion." (citation omitted)).

${ }^{126}$ See Hepler, supra note 86, at 93-94 (describing an American "civil religion" that cuts across minority group lines).

${ }^{127}$ See William P. Marshall, Religion as Ideas: Religion as Identity, $7 \mathrm{~J}$. CONIEMP. LEGAL ISSUES 385, 399 (1996) ("Disallowing one religion from gaining political advantage therefore may also have the additional salutary effect of preventing religiouslymotivated political confrontations from escalating.").

${ }^{123}$ Hall, supra note 13, at 81 (footnotes omitted); see also id. (arguing that when religious minorities "exclude themselves from the public square," political discourse is impoverished and the danger of majority tyranny is increased). 
pletely would be divisive as well, as it would encourage some religious individuals and groups to withdraw from the civic community. Such a result is clearly undesirable, but the complete separation of religious and civil life would be preferable to secularization because, at the very least, it would be sect-neutral. In addition, it would allow dissenters to maintain a distinction between their public and religious affiliations, a distinction which protesting individuals and groups are not permitted under the current scheme.

The sectarian nature of secularization exacerbates divisiveness. Secularization is selectively employed, and it reflects the experience and traditions of the majority. It affirms "the absorption of 'Christian ethnocentrism' into public institutions, and a 'ceremonial deism' that links democratic ideals and institutions to transcendent aspirations." ${ }^{\text {129 }}$ Indeed, the Court has sanctioned the secularization of only Jewish and Christian symbols and practices. The Court asserts that it is merely recognizing historical traditions which incidentally reference Jewish and Christian ideals, ${ }^{130}$ but even a seemingly innocuous acknowledgment of Jewish or Christian culture constitutes government identification of these religions with American national culture. By consistently celebrating Jewish and Christian traditions, even in a nominally secular fashion, the Court is supporting a sectarian construction which integrates certain religions into American culture. ${ }^{131}$ By holding that the crèche in Lynch was not truly religious, "the Court supports the construction of a putatively civil religion founded in Christian symbolism and backed by the state."132

This type of preference for sects, or for religion per se, foments divisiveness among sects and reiterates the force of religion in establishing political standing in the community. ${ }^{23}$ Religion scholar Ira

${ }^{129}$ Developments in the Law-Religion and the State, 100 HARV. L. REV. 1606, 1651-52 (1987) [hereinafter Developments in the Law] (footnotes omitted) (quoting respectively Van Alstyne, supra note 98, at 786; Lynch v. Donnelly, 465 U.S. 668, 716 (1984) (Brennan, J., dissenting) (internal quotation omitted)).

${ }^{130}$ See, e.g., County of Allegheny v. ACLU, 492 U.S. 573, 617 (1989) (plurality opinion) (concluding that when coupled with a Christmas tree, a menorah merely symbolizes the celebration of the "winter-holiday season"); Lynch, 465 U.S. at 681 (noting that there are "legitimate secular purposes" for a city's display of a crèche).

${ }^{131}$ See Dolgin, supra note 90, at 502-03 ("The majority opinion in Lynch invokes a set of American myths, reifies them, and then uses them to construct a civil religion that becomes isomorphic with the celebration of Christianity.").

${ }^{192}$ Id. at 505.

139 See Marshall, supra note 127, at 399 ("When the benefits and power of government are seen as off-limits to competing religious groups, the danger of religious divisiveness and factionalism subsides."). 
Lupu warns that " $[\mathrm{h}]$ istory provides us with abundant lessons of the unique dangers of encouraging sectarian competition .... State creation of explicitly sectarian benefits may foster resentment among sects, which in turn may aggravate preexisting and potentially destructive social divisions."

\section{G. Detriment to the Individual}

In addition to its effects on religion and society, secularization is severely detrimental to individuals. The Supreme Court justifies secularization by making sweeping and inaccurate assumptions about public interpretation and civil identification. Furthermore, the Court fails to confront the implications of exclusivity in its dubious notions of secularization. Supporters of the Court's secularization are not troubled because they fail to perceive how these practices injure individuals. ${ }^{135}$

\section{Minority Interpretation of Secularization}

The validity of secularization, as professed by the Court, relies on significant assumptions. In particular, the Court presupposes that it is possible for a religious practice or symbol to lose its religious meaning. The Court further assumes the loss to be generally understood within the relevant community. Given the disagreement among judges and legal scholars concerning the validity of this presumption, ${ }^{136}$ it is disconcerting that the Court would assume that citizens would be prepared to accept this leap of logic.

134 Ira C. Lupu, To Control Faction and Protect Liberty: A General Theory of the Religion Clauses, 7 J. CONTEMP. LEGAL IsSUES 357, 367-68 (1996).

135 See JeSSE H. CHOPER, SECURING Religious LIBERTY: PRINCIPLES FOR JUdicial. INTERPRETATION OF THE RELIGION CLAUSES 154 (1995) (noting that the Court correctly decided Lynch because "[n]o one was compelled or meaningfully influenced to do anything in respect to their religious beliefs, and to the extent that tax funds were used at present, the amount seems to have been de minimis").

196 See, e.g., County of Allegheny v. ACLU, 492 U.S. 573, 643 (1989) (Brennan, J., dissenting in part) ("The menorah is indisputably a religious symbol, used ritually in a celebration that has deep religious significance."); Sherman v. Community Consol. Sch. Dist. 21, 980 F.2d 437, 448 (7th Cir. 1992) (Manion, J., concurring) ("[A] court cannot deem any words to lose their meaning over the passage of time."); Dolgin, supra note 90, at 504 (arguing that "outside the fanciful world of the Lynch decision, the crèche remains a central embodiment of Christian theology"); Steven B. Epstein, Rethinking the Constitutionality of Ceremonial Deism, 96 COLUM. L. REV. 2083, 2165 (1996) ("[U]nder any honest appraisal of modern American society, the practices constituting ceremonial deism have not lost their religious significance."). 
In recent cases, the Supreme Court has determined whether secularization has been achieved by evaluating the practice or symbol in question under the endorsement test. ${ }^{137}$ The test asks whether a reasonable observer would perceive the practice or symbol as a government endorsement of religion. ${ }^{138}$ With regard to the crèche in Lynch and the menorah in Allegheny, the Justices applying the endorsement test determined that a reasonable observer would not perceive these symbols as representing a government endorsement of religion. ${ }^{139}$ This result is puzzling, for it requires that the reasonable observer be well versed in American culture and history, and at least somewhat familiar with church and state doctrine. Yet, without at least a minimal degree of familiarity with the Establishment Clause, it seems implausible that the average citizen would interpret a governmentsponsored crèche as anything but an endorsement of religion. It is doubtful that much of the current American population fits the profile of the Court's reasonable observer, and we can be certain that those unfamiliar with American culture do not. Constitutional law scholar William Van Alstyne notes this incongruity: "Late arrivals to America may suppose they can take the government's religiosity or leave it, but they are stuck with the reality that ... [o] urs is basically a Christian-pretending government where they will be made to feel ungrateful should they complain." 140

The Court is optimistic when it assumes that there is any single and predictable way of interpreting symbols. One religion scholar suggests that:

${ }^{137}$ See, e.g., Allegheny, 492 U.S. at 592 (stating that “[i]n recent years, we have paid particularly close attention to whether the challenged governmental practice either has the purpose or effect of 'endorsing' religion" (citing Engel v. Vitale, 370 U.S. 421, 436 (1962))); Lynch v. Donnelly, 465 U.S. 668, $687-88$ (1984) (O'Connor, J., concurring) (arguing that an Establishment Clause violation is present when government endorses or disapproves of a religion or becomes entangled with a religious institution).

Iss See Allegheny, 492 U.S. at 597 (plurality opinion) (holding that the Establishment Clause is violated when "the challenged governmental action is sufficiently likely to be perceived by adherents of the controlling denominations as an endorsement, and by the nonadherents as a disapproval of their individual religious choices" (quoting School Dist. of Grand Rapids v. Ball, 473 U.S. 373, 390 (1985))); Lynch, 465 U.S. at 692 (O'Connor, J., concurring) ("The display celebrates a public holiday, and no one contends that declaration of that holiday is understood to be an endorsement of religion.").

${ }_{199}$ See Allegheny, 492 U.S. at 620-21 (plurality opinion) (holding that an observer could not reasonably infer that the presentation of a menorah in this case represented an endorsement of religion); Lynch, 465 U.S. at 692 (O'Connor, J., concurring).

${ }^{140}$ Van Alstyne, supra note 98 , at 787. 
No symbol, religious or otherwise, has one meaning for everyone. The definition a person selects from available meanings depends on the use of the symbol for that person at a particular time and place.... [A] symbol with religious meanings may bear some of those meanings for some people, even if used in a nonreligious context ....

In order to understand that a crèche on government property is not an endorsement of Christianity, a reasonable observer must regard Christmas as a secular holiday. This is not an obvious interpretation. Christmas is, in fact, a day to commemorate the birth of Jesus Christ, the Christian Savior. Furthermore, the Court's reasonable observer in both of these situations would have to discern that accommodation of religion is distinct from endorsement. ${ }^{142}$ Under these circumstances, the Establishment Clause actively protects only those who resemble the Court's construction of a reasonable observer. This limitation cripples the Clause by compromising minority interests. Individuals who do not resemble the Court's imagined reasonable observer are denied the consideration that they deserve, the same protection afforded to mainstream citizens.

There is extensive evidence that the Court's construction of the reasonable observer is insufficient to protect the interests of minorities. ${ }^{143}$ For instance, in Lynch, substantial evidence was offered to indicate that religious minorities understood the crèche as a symbol of Christianity. These religious minorities were not persuaded by the surrounding holiday paraphernalia that the crèche was merely part of a secular celebration. ${ }^{144}$ One commentator observed that "the fact that [the crèche] ... is part of a wider secular celebration ... does not dilute the inevitable impression that the government is endorsing the beliefs associated with the crèche." 145 Similarly, it is at least plausible, if not probable, that a person uttering the Pledge of Allegiance

${ }^{141}$ Dolgin, supra note 90 , at 497-98 (footnotes omitted).

142 The Court has held that accommodation of religion is a valid secular purpose satisfying the first prong of the Lemon test. See, e.g., Corporation of the Presiding Bishop of the Church of Jesus Christ of Latter-Day Saints v. Amos, 483 U.S. 327, 338 (1987) ("[T]here is ample room for accommodation of religion under the Establishment Clause."); Zorach v. Clauson, 343 U.S. 306, 315 (1952) (holding that the release of students from school for religious instruction is a valid accommodation of religion and does not violate the Establishment Clause).

${ }^{143}$ Furthermore, it does not account for the multitudes who may not be considered "reasonable" by the Court and are therefore rendered outsiders.

${ }^{144}$ See Developments in the Law, supra note 129 , at 1657 \& $\mathrm{n} .85$ (referring to the testimony of a child psychologist in Lynch concerning the effects of Christian symbols like the crèche on non-Christian children).

${ }^{145} I d$. at 1657. 
for the first time would reasonably conclude that the government endorses allegiance to a religious deity. ${ }^{146}$ As conceived, the Court's test is optimistic and, indeed, misguided in its application, eviscerating the Establishment Clause by limiting its applicability.

\section{Denying Full Citizenship}

Secularization sacrifices minority interests in order to preserve agreeable traditions. This compromise brings with it a prohibitively high cost for a democratic and ostensibly pluralistic society. By assuming that secularization is commonly understood as an acknowledgment of religion for the sake of tradition, rather than an endorsement of particular religious ideals, ${ }^{147}$ the Court is effectively denying full citizenship to nonadherents. ${ }^{148}$ Madison recognized this danger when he wrote his Memorial and Remonstrance against the Virginia Assessment Bill, expressing his concern that the Bill "degrades from the equal rank of Citizens all those whose opinions in Religion do not bend to those of the Legislative authority."149 Indeed, a fundamental purpose of the Establishment Clause is to protect citizens who do not adhere to the majority religious beliefs. Although it is often argued that the Clause exists merely to prevent actual state support of a particular religion to the exclusion of another, ${ }^{150}$ it is clear

${ }^{146}$ The reasonable observer standard is particularly problematic in this context. The Pledge of Allegiance is frequently recited in schools, and it is unlikely that young children have the requisite experience with American culture to satisfy the reasonable observer test. In addition, the Pledge and other mottoes are often communicated to new immigrants, who certainly do not fit comfortably within the Court's construction of a reasonable observer but who nonetheless merit the protection of the Bill of Rights.

${ }^{147}$ See supra Part II (questioning the coherence of the secularization approach).

${ }^{149}$ See Hall, supra note 13 , at $80-81$ (arguing that civic religious activities may "coerce citizens to deny their citizenship rather than submit to an unholy spiritual fellowship").

149 MADISON, supra note 112, reprinted in THE MIND OF THE FOUNDER, supra note 112 , at $10-11$.

${ }_{150}$ See, e.g., Wallace v. Jaffree, 472 U.S. 38, 98 (1985) (Rehnquist, J., dissenting) (interpreting the Framers' intent when creating the First Amendment as “designed to prohibit the establishment of a national religion, and perhaps to prevent discrimination among sects"); cf. Andrew Rotstein, Note, Good Faith? Religious-Secular Parallelism and the Establishment Clause, 93 CoLUM. L. REv. 1763, 1795-96 (1993) ("So long as there is no endorsement of religion qua religion, and no implication that the benevolent acknowledgment of one religion's universal message in any way excludes or demeans the messages of other religions or the beliefs of nonreligious persons, there seems no reasonable ground for the objective observer to feel relegated to the role of an outsider or one of inferior political status or otherwise feel coerced or offended." (footnote omitted)). 
that secularization forces outsiders to recognize and often assert their status as outsiders. The Court, however, ends its inquiry after concluding that a given practice is simply no longer religious. As attractive as this analysis may be to those committed to preserving public invocations, it effectively deprives dissenting individuals of their untainted claim to citizenship.

The consequences of secularization are detrimental, and its practical effect poses an ironic compromise: The very declaration that a practice or symbol has lost its religious significance insults religion by depriving it of its inherent holiness. ${ }^{151}$ Yet it also alienates outsiders insofar as such declarations are ineffective. Religion is injured by government encroachment and spiritual pollution, and, notwithstanding the Supreme Court's attempts to neutralize the religiousness of secularized practices and symbols, society and individuals are injured by perceptions that the government is privileging religion, thereby denying full citizenship to those outside the mainstream. In this sense, both the winners and the losers suffer, raising the question of why the courts perform such logical gymnastics in order to preserve these traditions.

\section{SECULARIZATION AND THE CRISIS OF AMERICAN IDENTITY}

Assessing the damage of Supreme Court secularization of religious symbols and practices presents puzzling questions. If the consequences of secularization are so severe, why does the Court persist? Why does secularization not meet greater opposition? In this Part of the Comment, I argue that the pursuit of secularization analysis is a desperate and misguided attempt to preserve a particular construction of American identity that is based largely on the Christian and Jewish traditions. Secularization facilitates a myth of collective American identity which relies on religion in general, and Christian and Jewish traditions in particular, to buttress that construction. The secularization analysis is both an inadequate and a wholly inappropriate means of achieving the questionable goal of curing our national identity crisis. ion)

${ }^{151}$ See supra Part IV.A (describing the harms that secularization inflicts on relig- 


\section{A. Collective Identity Crisis}

The notion articulated by Justice Douglas that "[w]e are a religious people whose institutions presuppose a Supreme Being," 152 offered as justification for Supreme Court doctrine, ${ }^{153}$ reveals the depth of investment in religion as a defining characteristic of our national identity. The statement does not merely indicate that many Americans are religious, or that religion is central in the lives of some individuals-rather, it defines America collectively as a religious body. Yet the correlation between a nation composed of religious individuals and a "religious people" is not obvious. In the same way that the fact that eighty percent of Americans are Caucasian ${ }^{154}$ does not make us a "white people," the prevalence of religious affiliation does not necessarily make us a "religious people." It is clear, however, that this vision of an American identity based largely on religion has broad support. ${ }^{155}$ The prevalence of this view alone, however, does not suggest any convincing explanation for its continued existence.

The investment in religion as a pillar of our national identity is evident even in the language adopted by those who criticize the Supreme Court's secularization analysis. Even scholars who criticize the present Supreme Court methodology frequently suggest alternative

${ }^{152}$ Zorach v. Clauson, 343 U.S. 306, 313 (1952). The Court in Zorach used this claim to uphold the constitutionality of a program that allowed public schools to release students during school time for private religious instruction off-site. To do otherwise, the Court said, would be to "read into the Bill of Rights . . . a philosophy of hostility to religion." Id. at 315.

${ }^{153}$ This phrase has been cited in a number of other Supreme Court and lower court opinions. See, e.g., Bender v. Williamsport Area Sch. Dist., 475 U.S. 534, 554 (1986) (Burger, C.J., dissenting); Lynch v. Donnelly, 465 U.S. 668, 675 (1984); Marsh v. Chambers, 463 U.S. 783, 792 (1983); Meek v. Pittenger, 421 U.S. 349, 395 (1975) (Rehnquist, J., dissenting in part); Walz v. Tax Comm'n, 397 U.S. 664, 672 (1970); McGowan v. Maryland, 366 U.S. 420, 563 (1961) (Douglas, J., dissenting).

${ }^{154}$ See THE WORLD ALMANAC AND BOOK OF FACTS 1997, at 379 (Robert Famighetti ed., 1996).

${ }^{135}$ See, e.g., ARIIN M. ADAMS \& CharLes J. EMMERICH, A NATION DEDICATED to RELIGIOUS LIBERTY 82 (1990) ("American culture can ... be seen as a tapestry, with religion as its warp threads."); Dolgin, supra note 90, at 516 (interpreting the Supreme Court's decision in Lynch as based on the proposition that "Christianity and the American nation become one"); Maddigan, supra note 71, at 326 (asserting that American identity is dependent "on some notions that happen to overlap with traditional religion," and predicting that "[u]ndermining these notions would actually undermine the identity of the entire society, whose members-including atheistsdepend on these collective norms to remain connected with the whole"); M.G. "Pat" Robertson, Religion in the Classroom, 4 WM. \& MARY BILL RTS. J. 595, 601 (1995) (describing Justice Douglas's characterization as "the best summation of our religious history"). 
analyses that will save such practices, ${ }^{156}$ revealing their own investment in the myth of a religious identity. Advocates of civil religion and its preservation in public life acknowledge that "public religion 'feels funny,' constitutionally speaking, and is not readily understandable or justifiable in the terms through which the establishment clause is generally understood." ${ }^{157}$ As a remedy, those same critics suggest overt reliance on civil religion as a justification for practices and symbols that otherwise would be unconstitutional. ${ }^{158}$ Absent a deep investment in the notion of a "religious people," it is not clear why the Court should engage in contortions of logic to justify the inclusion of religion in public life. What would be lost by applying a more straightforward interpretation of the Establishment Clause?

One plausible explanation for the continued efforts to maintain religion's privileged position in American identity arises from the common association of religion with morality. ${ }^{159}$ Many commentators advocate retention of religion in public life because they regard religion as a bastion of morality, and they fear the demise of morality in contemporary culture:

[W]ithout religious principle to guide them, people will tend to be immoral and careless about marital obligations. They will, if it suits their interests, lie, cheat, steal, commit violent acts, and abuse drugs and alcohol. Guards and metal detectors, more prisons, and expanded death sentences will not deter them in the absence of religious principle.

156 See, e.g., Maddigan, supra note 71, at 345-46 (arguing that civil religion provides a theoretical framework for justifying public prayer and the words "under God" in the Pledge and "In God We Trust" on coins); Mirsky, supra note 71, at 1255 (suggesting a means by which "judicial sensibility ... could respond creatively to the constitutional vagaries of public religion"); of. Rotstein, supra note 150, at 1795-96 (suggesting an "objective observer" approach).

${ }^{157}$ Mirsky, supra note 71, at 1239.

${ }^{158}$ See, e.g., Maddigan, supra note 71, at 346 (advocating the concept of civil religion to "justify longstanding cultural practices that... might be found unconstitutional" ${ }^{\prime}$ ); Mirsky, supra note 71, at 1255 (suggesting that the Court employ civil religion to "shape the more troubling manifestations of civil religion into a more constitutionally palatable form").

${ }_{159}$ See, e.g., Maddigan, supra note 71, at 327 ("To refuse to permit the government to help promote basic values-like honesty, hard work, and mutual care-on which democracy depends merely because these values are also embraced by theological religions is hardly desirable."); Robertson, supra note 155, at 597 (citing George Washington for the proposition that "reason and experience forbid us to expect public morality in the absence of religious principle"); Rotstein, supra note 150 , at 1805 ("American public values, as reflected in the Constitution itself, are not entirely distinguishable from fundamental moral concerns that religion also addresses.").

${ }^{160}$ Robertson, supra note 155 , at 597. 
Yet even if such despairing predictions are not entirely unreasonable, panic about the health of our collective moral soul does not justify manipulating our constitutional jurisprudence to assuage the fears of a few. ${ }^{161}$ Although it is true that tenets of many religions coincide with basic notions of morality, and religion may be a useful vehicle for promoting these notions, asserting that morality will vanish from society in the absence of a strong identification of Americans as "religious people" is simply wrong. It is also offensive to ethical and moral atheists. Furthermore, when compared with alternative means of inculcating morality, secularization of religion bears a much higher cost. $^{162}$

The subtext of the language employed by advocates of civil religion and supporters of the Court's secularization practice reveals a fundamental concern for the American identity. The need to redefine crèches as secular and to preserve God in our national pledge and in our legislatures seems to be motivated by a collective identity crisis. Proponents accurately note that religion has been an important element in the development of American culture. ${ }^{163}$ It is not clear, however, how a government without this secularized religious influence will, as one supporter of the Court's jurisprudence argues, be "debilitating in the sense that a government that scrupulously avoids any hint of transcendent, ultimate, or even visionary goals or values in its statecraft tends to become an antiseptic technocracy... with no role in fostering the civic or moral development of

${ }^{161}$ Although some legal scholars advocate formal adoption by the Court of a civil religion in order to justify secularization and preserve public religion, others champion an amendment to the Constitution specifically preserving such public religion as prayer in public schools. See, e.g., Harlan A. Loeb \& Debbie N. Kaminer, God, Money and Schools: Voucher Programs Impugn the Separation of Church and State, $30 \mathrm{~J}$. MARHSALL L. REV. 1, 2 (1996) (noting that both the Christian Coalition and Focus on the Family have proposed constitutional amendments allowing prayer in school). An amendment, subject to the legislative process and ratification by the states, is more palatable than judicial maneuvering intended to redefine nativity scenes as "national" or "secular" symbols.

${ }_{162}$ See Kaufman, supra note 6, at A15 ("Pathetically, laws establishing religious parameters of conduct may become the new moral surrogate for some families in the 1990s. Exactly what may come of this misguided substitution of assigned roles-jurist as spiritual mentor, legislator as itinerant preacher-is yet unknown.").

${ }_{163}$ See, e.g., Maddigan, supra note 71, at 316-17 (asserting that "religion has always played a prominent role in American civil society"); Mirsky, supra note 71, at 1240 (describing religion as a "meaningful element of American life"); Robertson, supra note 155, at 601 ("Vestiges of our religious history still live in the public life of America."). 
the individual." 164 The "essential" union of religion and state is not at all clear. Supporters often fail to justify the contortions of constitutional jurisprudence in the name of preserving the religious elements they understand as fundamental to national identity. Furthermore, supporters of secularization and the preservation of public religion refuse to divorce the past from the present; the boundaries between religion and the secular have shifted over time with the dramatic evolution of the nation's demographic composition. ${ }^{165}$ Although Christian traditions may have harmonized with the national identity of the late eighteenth century, no sectarian representation, indeed, no religious identification at all, is compatible with a conscientious expression of a contemporary national identity. ${ }^{166}$

\section{B. Proposing an Alternative}

When examined in light of the serious consequences of secularization, the justification for maintaining religion in public life as a means of preserving a particular construction of American identity cannot be sustained. Such a rationale is not sufficiently strong to outweigh the need for rigorous legal analysis. The Supreme Court should, therefore, undertake an approach both simple and radical: It should abandon its policy of secularizing religious practices and symbols and return to the Establishment Clause analysis which it employed in its earliest cases. Such a proposal requires only that the Court return to the principles and methodologies established in the earliest incarnations of church and state doctrine, ${ }^{167}$ though the proposal would achieve dramatic results. By abandoning secularization analysis, the Court would no longer be able to recharacterize religious

${ }^{164}$ Rotstein, supra note 150 , at 1802.

${ }^{165}$ For example, Islam recently surpassed Judaism as the second largest faith in the United States. See Epstein, supra note 136, at 2084 n.I (citing Sylvester Monroe, The Fruits of Islam: Muslim Faith Grows in Followers and Respect, EMERGE, Mar. 1994, at 38, 40).

${ }^{166}$ In the early years of the nation's existence, religion, especially Christianity, may have fit harmoniously at the center of the population's identity. See CURRY, supra note 73, at 218 (arguing that in the late eighteenth century, "Protestant Christianity and American culture intertwined"). Furthermore, because many settlers had left Europe to escape religious oppression, it seems natural that religion was a defining characteristic of their collective identity.

${ }^{167}$ For example, the modern Court should look to the majority decision in School District of Abington Township v. Schempp, 374 U.S. 203, 226-27 (1963). In that case the Court adhered to the interpretation of the Establishment Clause articulated in Everson v. Board of Education, 330 U.S. 1 (1947), and struck down local school prayer initiatives despite their popularity. 
practices and symbols as secular, and therefore, these contested practices and symbols would be expelled from public life.

Faithful application of the Establishment Clause could be achieved by rigorous application of tests currently used by the Supreme Court. For example, if the Court evaluated the facts of Allegheny in accordance with the endorsement test, but in the absence of secularization, both the nativity crèche and the menorah would have been held unconstitutional. ${ }^{168}$ The first prong, which requires an examination of whether the displays have a valid secular purpose, ${ }^{169}$ is satisfied under the Court's actual analysis and under the proposed analysis. ${ }^{170}$ The second prong is an inquiry into the effects of the practice: Does the presence of the crèche or the menorah have the effect of conveying a government endorsement of religion ? $^{171}$ The holdings in the actual opinion relied on an assessment of whether, in the context of each display, the symbols were truly religious, or whether their surroundings had transformed them into secular objects. Hence, the crèche, which stood alone, was religious and violated the effects prong because it could be reasonably interpreted as an endorsement of religion. ${ }^{172}$ The menorah, however, was surrounded by other holiday paraphernalia, and therefore could not be reasonably perceived as government endorsement of religion. ${ }^{173}$ According to the Court's opinion, context had somehow neutralized the religiousness of the objects. However, if evaluated according to the proposed analysis, both displays would be examined in accordance with their original, religious connotations, not as interpreted by a modern Court's fictitious reasonable observer, and unmitigated by holiday traditions. This approach is somewhat of a lowest-commondenominator analysis: It strips the practices and objects to their essential form and function, as naturally understood by an uninformed

${ }^{169}$ The endorsement test is one possible means of analyzing such cases. Other tests employed by the Court, such as the Lemon test, would be adequate if applied in the absence of secularization analysis. This suggests that while much controversy has surrounded the appropriate test for adjudicating Establishment Clause claims, the application of such tests is a more fundamental problem.

${ }^{169}$ See Lemon v. Kurtzman, 403 U.S. 602, 612-13 (1971).

${ }^{170}$ This prong is satisfied under the proposed analysis only because the Court has consistently held that the practice in question must only demonstrate a plausible secular purpose, not that the only conceivable purpose be secular. See, e.g., Wallace v. Jaffree, 472 U.S. 38,56 (1985) (finding the purpose prong violated when the statute in question "had no secular purpose").

171 See County of Allegheny v. ACLU, 492 U.S. 573, 592-94 (1989).

172 See id. at 601-02.

${ }^{173}$ See id. at 620 (plurality opinion). 
observer and devoid of implications and meanings ascribed to them by the Supreme Court and legal scholars. In short, under the proposed analysis, a crèche is a Christian symbol commemorating the birth of Christ; no philosophical or social reconstruction can or should alter this essential symbolism.

Regardless of whether the Court analyzes challenged symbols and practices under its traditional tests or an alternative inquiry, the proposal requires more stringent scrutiny of the object or practice being challenged. In addition to banning crèches and menorahs from government-sponsored displays, the proposed analysis would also eliminate national invocations of God in our mottoes and Pledge, and on our currency. Religion would have to be absent from governmentsponsored events and activities. Although this result seems radical, and indeed would have a profound effect, it would not deprive American culture of all symbols and invocations; rather, it would result in an increased reliance on the symbols and practices that are truly representative of our national identity, such as the flag, recitation of the Pledge of Allegiance as it was initially conceived, ${ }^{174}$ and invocations celebrating our rich secular history as a nation of individuals united by an allegiance to democracy and freedom, not to God.

\section{CONCLUSION}

Secularization is an unfortunate means of attempting to maintain the status quo. It is legally and analytically unsound and, perhaps more important, it has harmful consequences. Regardless of the myriad ways in which the practice is recast by scholars as a legitimate incorporation of civil religion, secularization extracts a high cost from religion, society, and individuals.

Repudiation of Supreme Court sanctioning of public religion through its practice of secularization is a radical proposal; without the logic of secularization, the Court would be unable to preserve many public religious traditions. Although a rigorous application of Establishment Clause analysis would eradicate crèches from our public squares and "God" from our national mottoes, pledges, and invocations, it would return church and state jurisprudence to an acceptable level of judicial integrity. Furthermore, elimination of Court seculari-

${ }^{174}$ The original Pledge of Allegiance did not include the phrase "under God" and merely affirmed allegiance to "one nation, indivisible, with liberty and justice for all." The invocation to God was added in the 1950s. See ANSON PHELPS STOKES \& LEO PFEFFE, CHURCH AND STATE IN THE UNITED STATES 570-71 (1964). 
zation would allow religion to subsist without either assistance or interference from government, and more importantly, would grant full enjoyment of citizenship to all, regardless of any religious affiliation. 
$* * * * * *$ 